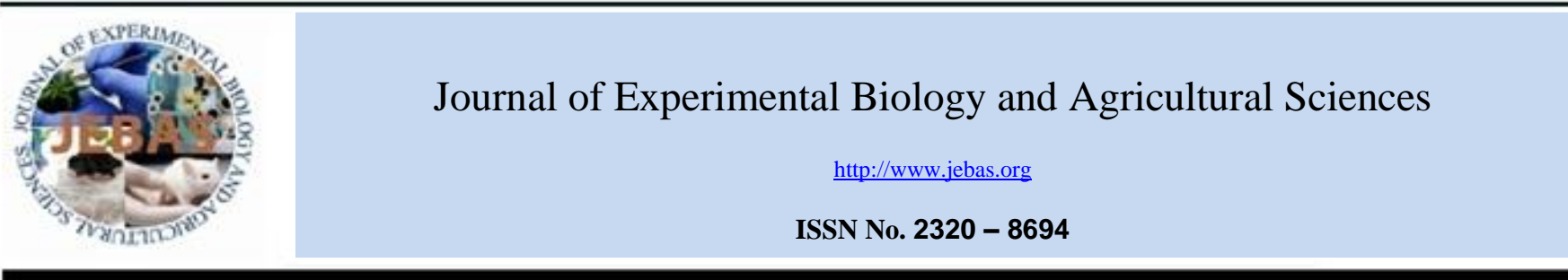

\title{
METHODOLOGY CONSIDERATIONS FOR THE MOLECULAR DETECTION OF TORCH ORGANISMS USING PCR APPROACHES
}

\section{Bhumika Prajapati $^{1}$ (D), Kranti Vora ${ }^{1}$ (D), Aarthi Sundararajan ${ }^{1}$, Shahin Saiyed ${ }^{1}$, Ruchi Tiwari ${ }^{2}$ (D), Kuldeep Dhama ${ }^{3}$ (D), Senthilkumar Natesan ${ }^{1}$ (D)}

\footnotetext{
${ }^{1}$ Indian Institute of Public Health Gandhinagar, Lekawada, Gandhinagar, Gujarat, 382042, India

${ }^{2}$ Department of Veterinary Microbiology and Immunology, College of Veterinary Sciences, Deen Dayal Upadhayay Pashu Chikitsa Vigyan Vishwavidyalay Evum GoAnusandhan Sansthan (DUVASU), Mathura, 281001, India

${ }^{3}$ Division of Pathology, ICAR-Indian Veterinary Research Institute, Izatnagar, Bareilly, Uttar Pradesh, 2431224, India
}

Received - November 02, 2020; Revision - November 25, 2020; Accepted - December 17, 2020

Available Online - December 30, 2020

DOI: http://dx.doi.org/10.18006/2020.8(6).743.757

\section{KEYWORDS}

TORCH complex pathogens

Molecular assay

Gene target

Variable factor

PCR

Diagnosis

\begin{abstract}
There is a need for a reliable and cost-effective molecular diagnostic assay for the diagnosis of TORCH [Toxoplasma gondii, Other (Varicella-Zoster virus and Parvovirus B19), Rubella virus, Cytomegalovirus, and Herpes Simplex virus] infections. This would enable early and precise detection of pathogens even in a very low copy number. However, the selection of genomic target, specimen matrix, and different PCR methods can significantly affect the sensitivity and specificity of TORCH molecular detection. This review aimed to provide a comparative analysis of clinical sample types, target nucleotide sequences, and PCR detection approaches for molecular detection of TORCH organisms. This review will aid in the development of a sensitive molecular assay for quick and precise detection of TORCH organisms.
\end{abstract}

* Corresponding author

E-mail: snatesan@iiphg.org (Senthilkumar Natesan)

Peer review under responsibility of Journal of Experimental Biology and Agricultural Sciences.

Production and Hosting by Horizon Publisher India [HPI] (http://www.horizonpublisherindia.in/).

All rights reserved.
All the articles published by Journal of Experimental Biology and Agricultural Sciences are licensed under a Creative Commons Attribution-NonCommercial 4.0 International License Based on a work at www.jebas.org.

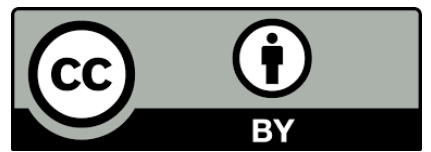




\section{Introduction}

TORCH is a group of infectious organisms including Toxoplasma gondii (T. gondii), Other [Varicella-Zoster virus (VZV), Hepatitis B, and Parvovirus B19 (B19V)], Rubella virus (RubV), Cytomegalovirus (CMV), and Herpes Simplex virus (HSV) (Yadav et al., 2014; Prasoona et al., 2015; Neu et al., 2015; Cofre et al., 2016). This is commonly found in a fetus or newborn showing clinical features well-matched with a vertically acquired infection and requires coherent diagnostic and treatment approaches. Infections such as these during pregnancy are a major cause of congenital abnormalities and fetal damage or loss. However, the period of gestation during which infection occurs determines the degree of severity experienced by the fetus (Yadav et al., 2014; Neu et al., 2015). TORCH infections have an immense public health impact. In US alone, around 30,000 children $(\sim 1$ in 150$)$ are born with congenital CMV, a member of TORCH infections, each year and around 5500 of them experience some form of such as deafness, blindness, and intellectual disabilities (Dollard et al., 2007; Cannon et al., 2012). Several methods such as serology, enzyme-linked immunosorbent assays (ELISAs), direct agglutination tests, complement fixation tests, virus isolation, histopathology, and nucleic acid based molecular assays, are currently used to screen for TORCH infection (Paiva-Cavalcanti et al., 2010; Sen et al., 2012; Wang et al., 2015; Suviriyapaisal et al., 2017; Dominguez et al., 2018; Ahmadpour et al., 2019). The traditional "TORCH test" is no longer suitable and has been replaced by specific tests for specific pathogens in well-defined situations. In the recent era of genomics, molecular approaches have become an essential standard to detect specific organisms, monitor infections, and quantify viral loads.

Despite the potential for sensitive pathogen detection offered by molecular methods, there are several pitfalls limiting their optimal performance. PCR based methods depend on the selection of 'primers', which can affect the performance the assay depending on their nucleotide sequences, secondary structures, and the formation of undesired inter- or intra-molecular interactions. Additionally, PCR based methods also depend on the specimen type, nucleic acid extraction method, concentration of nucleic acids, presence of PCR inhibitors, PCR conditions, and specific type of PCR, i.e., conventional PCR (cPCR), nested PCR (nPCR), or real-time quantitative PCR (qPCR) (Rodrigues et al., 2013). For an efficient and accurate detection of any organism using PCR, specimen and primer selection is a crucial process (Petrik, 2001; Lorenz, 2012).

The development of in-house molecular assays for detecting TORCH infections requires deep theoretical knowledge of the causative pathogens and cautions to account for genomic variations that may affect the assay sensitivity and specificity. There is a substantial amount of work published on the detection of specific TORCH organisms individually by targeting different genomic regions from a variety of samples; however, there is currently no comparative analysis of these approaches. Therefore, we attempted to comprehensively review the published work regarding molecular detection of TORCH organisms with respect to the clinical specimen, target gene selection, primer selection, and assay methodology. The aim of this paper was to review the development and validation of PCR assays for detecting TORCH organisms, including factors that can affect the overall assay sensitivity and specificity.

\section{Toxoplasma gondii}

\subsection{Specimen selection}

Toxoplasmosis must be diagnosed early during pregnancy to offer early treatment and reduce the possibility of congenital infection in the fetus (Emna et al., 2006; Ahmadpour et al., 2019). PCR detection of $T$. gondii is a rapid and sensitive method to detect pathogen DNA in a wide range of clinical or non-clinical specimens. Whole blood (WB), along with its components; i.e., serum, plasma, peripheral blood mononuclear cells (PBMCs), buffy coat, and other bodily fluids, including amniotic fluids, can be tested using PCR. However, there is no consensus on the optimal sample for use in $T$. gondii detection (Contini et al., 2006). The French National Reference Centre for toxoplasmosis has advised the medical community on proposing guidelines regarding sample selection for molecular detection methods (Sterkers et al., 2010; Varlet-Marie et al., 2014). Molecular detection of circulating parasite DNA is beneficial for serology-based diagnosis. Research in animal models has preferred using the buffy coat over WB and has focused on the importance of blood volume for increasing PCR sensitivity. A 15-fold increase in sensitivity was observed with buffy coat isolated from a higher volume $(7 \mathrm{ml})$ of blood compared to WB, plasma, and buffy coat from a smaller volume $(200 \mu \mathrm{l})$ of blood (Brenier-Pinchart et al., 2015). Most studies have evaluated the performance of the PCR assay using blood sample volumes of 5 or 10 mL ( Khalifa et al., 1994; Dupon et al., 1995; Lamoril et al., 1996; Bourdin et al., 2014; Robert-Gangneux et al., 2015), although some used only $1 \mathrm{~mL}$ (Correia et al., 2010; Cardona et al., 2011). Samples with lower blood volumes may explain the poor sensitivity of PCR assays given the decreased number of nucleated cells in the sample ( Akane et al., 1994; Ajzenberg, 2010). Additionally, WB contains more potential PCR inhibitors, with heme being known to be a severe PCR inhibitor (Akane et al., 1994). In contrast, the use of peripheral blood has been reported to provide good sensitivity detecting $T$. gondii DNA in pregnant women (Bin Dajem \& Almushait, 2012). Positive maternal diagnosis should be accompanied by fetal diagnosis. Toxoplasma DNA amplification from amniotic fluid has been considered the most sensitive and safest method for prenatal diagnosis and has replaced direct sampling of fetal blood. It is also highly suggestive of acute infections acquired during gestation (Montoya et al., 2002; Nimri et al., 2004;). However, amniocentesis for PCR is not recommended for pregnant women with human immunodeficiency virus (HIV) infection due to procedural risks of fetal HIV transmission (Romand et al., 2001). 


\subsection{Target sequence selection}

The presence of $T$. gondii in biological samples can be detected through PCR by targeting its genetic material. The selection of $T$. gondii DNA target for PCR is still debated because different reports have suggested variable sensitivities depending on the target. To achieve higher sensitivity, the target sequence should be present in multiple copies and should be species-specific. Numerous multicopy genes, such as B1, 529 bp repeat element (REP529), internal transcribed spacer (ITS-1), and 18S rDNA, are widely targeted for detection of T. gondii in biological samples (Jauregui et al., 2001; Cristina et al., 1992). The non-coding repetitive element of $T$. gondii (TGR1E) has also been evaluated as a diagnostic PCR target ( Robert et al., 1996; Cermakova et al., 2005) but was abandoned due to sequence heterogeneity. The major surface antigen, the single copy gene P30 (P30, X14080.1), is also targeted for toxoplasmosis detection ( Howe \& Sibley, 1995; Rinder et al., 1995; Wang \& Yin, 2014). However, the sensitivity to detect the parasite varies with each target gene. The B1 and REP529 regions are the two most frequently used target sequences and multiple primers have been designed that can anneal to various locations of these genes (Burg et al., 1989; Homan et al., 2000). Sequence analysis of REP529 indicated a highly conserved nucleotide sequence across various isolates of $T$. gondii, and targeting REP529 resulted in a 10-fold increase in sensitivity compared to B1 (Veronesi et al., 2017). In one study, a RE6P529 targeted PCR assay showed significantly higher $(p<0.05)$ sensitivity than a B1-PCR assay across 16 positive samples (Reischl et al., 2003). Targeting REP529 has also been reported to be more sensitive than B1 and enabled increased performance of toxoplasma diagnosis in all tested biological samples (placenta, amniotic fluid, WB, aqueous humour, cerebrospinal fluid (CSF), and bronchoalveolar fluid (Cassaing et al., 2006). Another study compared targeting REP529 and B1 in 76 blood samples and found 31/69 (45.6\%) positive samples using REP529 targeted qPCR, none of which were detected with the B1 targeting assay. This indicates the superiority of REP529 targeting for the diagnosis of toxoplasmosis (Belaz et al., 2015). REP529 and B1 targeted PCR assays were found to have detection limits of 8 (640 fg) and 64 (5.12 pg) tachyzoites, respectively, in blood samples from leukemic children (Fallahi et al., 2014).

In contrast, the B1 targeting assay has been reported to be more efficient than REP529 because portions of the REP529 sequence were found to be absent from the parasite's genome in $4.8 \%$ of human T. gondii-positive samples (Wahab et al., 2010; Bin Dajem \& Almushait, 2012). The serologically negative samples from 150 pregnant women were found to be positive by B1 targeting PCR assay, establishing $\mathrm{B} 1$ as a sensitive and specific target with a detection limit of 12 tachyzoites (Bin Dajem \& Almushait, 2012). Mousavi et al. (2016) reported parasite prevalence of $67.8 \%$ and $57.1 \%$ by targeting B1 and REP529, respectively, in diabetic patients. A comparative study focused on the detection of $T$. gondii DNA using three primer sets targeting B1, 18S, and P30 found that primers targeting P30 and ribosomal DNA (18S) were able to detect $1 \mathrm{pg}$ of $T$. gondii DNA whereas B1 targeting primers detected as little as $50 \mathrm{fg}$ (single tachyzoites). Additionally, sensitivity was not compromised when using B1 primers in the presence of substantial amounts of human lymphocyte DNA (Jones et al., 2000). Recent research from south India investigating the detection of toxoplasmosis in a variety of animal tissue reported B1 PCR to be $100 \%$ sensitive and specific (Rajendran et al., 2018). Other studies have also found B1 to be a more sensitive and specific target than REP529 for toxoplasmosis diagnosis using both nPCR and qPCR assays ( Pereira-Chioccola et al., 2009; Mesquita et al., 2010; AlHadraawy \& Hadi, 2017). Due to unavailability of specific primers, one recent work analyzed a set of 685 sequences from different $T$. gondii strains and reported the GRA7 gene to be a suitable target for primer design and the sensitivity of the GRA7 targeting assay was found to be similar to REP529 targeting and 40-fold higher than the B1 targeting assay (Costa et al., 2016). The repetitive mobile genetic elements (MGEs), with 100-500 copies per cell, are also targeted for molecular diagnostics, but are not completely species-specific (Ossorio et al., 1991). Among all targets, B1 and REP529 appear to be the most sensitive targets for detecting $T$. gondii DNA and have been successful in ocular fluids and retinal sections (Wells et al., 2015). Therefore, these genomic sequences should be targeted in PCR based assays to achieve efficient detection of the parasite.

\subsection{Selection of PCR approach}

Along with the specimen type and target genomic sequence, the type of molecular method used, i.e., cPCR, nPCR, qPCR, multiplex PCR, and loop-mediated isothermal amplification (LAMP), can also affect the sensitivity of parasite detection (Su et al., 2010). Initially, cPCR based in-house and commercial kits were the only choice for molecular detection of TORCH infection in most laboratories (Lavrard et al., 1995). Later, nPCR was introduced to increase the sensitivity of molecular detection. However, over the past few years, real time qPCR, with its ability to quantify parasite levels in clinical samples and monitor the infection, has been recognized as the most sensitive and specific molecular method for TORCH detection (Edvinsson et al., 2006; Djurkovic-Djakovic et al., 2012). The technical performance of three PCR assays, cPCR, nPCR, and qPCR, has been compared for the detection of $T$. gondii in non-immune pregnant women using $\mathrm{B} 1$ as the target gene. This showed that cPCR, nPCR, and qPCR detected 8, 11, and 12 cases of toxoplasmosis with a sensitivity of $67.0 \%, 92.0 \%$ and $100 \%$, respectively, proving that $\mathrm{qPCR}$ is the most sensitive PCR assay (Aal et al., 2014). A comparison of four molecular assays observed a sensitivity of $84.7 \%, 98.3 \%, 96.6 \%$, and 98.3 and efficiency of $91.0 \%, 95.0 \%, 98.0 \%$, and $99.0 \%$ for cPCR, nPCR, multiplex nPCR, and $\mathrm{qPCR}$, respectively in the diagnosis of toxoplasmosis in amniotic 
fluid samples from 100 pregnant women. However, the same specificity, approximately $100 \%$, was reported for all PCR methods (Teixeira et al., 2013).

In 64 amniotic fluid samples subjected to toxoplasma detection, the detection limit of cPCR was found to be 1000 parasites while real time qPCR with SYBR Green was able to detect 10-100 parasites. Real-time qPCR using hybridization probes based on fluorescence energy transfer (FRET) was able to detect single parasite and is thus considered the fastest and most sensitive method (Nagy et al., 2006) cPCR and qPCR assays were recently developed and evaluated to estimate a lower limit of detection and specificity when targeting B1 of $T$. gondii. By both methods, the lower detection limit for $T$. gondii DNA was found to be $10 \mathrm{pg}$, equivalent to 0.01 tachyzoites per $\mu 1$ (Suviriyapaisal et al., 2017). LAMP is a nucleic acid amplification method that uses a polymerase enzyme with displacement activity and a set of four specially designed primers that recognize a total of six distinct sequences on the target DNA (Zhang et al., 2009). Comparing cPCR and LAMP identified detection limits of 10 and 1 $\mathrm{pg}$, respectively, where $1 \mathrm{pg}$ represents single $T$. gondii tachyzoites (Lau et al., 2010). LAMP assays have been reported to be 10 times more sensitive than nPCR, with a detection limit of 0.1 tachyzoites for detecting Toxoplasma DNA (Nagamine et al., 2002). The increased sensitivity and specificity of LAMP can be attributed to the increased number of primer pairs, which target six divergent regions of the target DNA (Shen et al., 1993).

\section{Human Cytomegalovirus (HCMV)}

\subsection{Specimen selection}

Sample type is an important preanalytical variable for detecting HCMV DNA. The virus can be detected in different fractions (cellular and cell-free) of blood and other bodily fluids, including urine, CSF, semen, vaginal secretions, umbilical cord blood (UCB), amniotic fluid, and throat washes (Razonable et al., 2001). However, the optimal specimen selection for CMV detection is still under the discussion. CMV is found to be excreted in multiple biological samples, but urine, blood, and amniotic fluids are the most commonly tested specimens. CMV establishes a lifelong latent infection following primary infection but may reactivate at any time owing to its shedding in urine, saliva, and other bodily fluids (Deback et al., 2007; Zhou et al., 2007). The peripheral blood lymphocytes have been reported for their increased sensitivity (Yerly et al., 2007), but their use is limited in leucopenia.

WB with anticoagulant has been suggested to be the ideal specimen given its higher DNA yield (Ross et al., 2011); however, serum or plasma is preferred for their accepted analytical performance and easier sample processing ( Li et al., 2003; Arora et al., 2010). Due to persistence of virus for a month after primary infection during pregnancy, it can be easily detected in peripheral blood samples
(Madrid et al., 2018; Martin Ramirez et al., 2019). Numerous studies have identified HCMV DNA in pregnant women and found a relationship to the outcome of congenital infection ( Munro et al., 2005; Revello et al., 2011). Fabrii et al. (2011) and Kaneko et al. (2006) assessed cord blood sera, Revello et al. (2011) evaluated amniotic fluids, and Munro et al. (2005) used maternal urine samples for HCMV detection. During the active phase of infection, virus is released from white blood cells (leucocytes), reticuloendothelial, and endothelial cells into the blood plasma, thus plasma viral load can indicate active HCMV infections. However, its absence does not exclude an active infection because the assay has a low detection limit, or the level of viral infection could be low. In contrast, one report has suggested, in cases of high viral load, that DNA can be detected more frequently in WB than plasma or serum due to the strict cell-associated nature of the virus (Garrigue et al., 2008).

Each type of sample has its own advantages and limitations, hence specimen selection for laboratory setup remains unsolved. WB is easier to process due to absence of cell separation steps, but viral testing from WB is susceptible to amplification inhibition from degraded hemoglobin products (Loens et al., 2007). In contrast, HCMV DNA quantification is easy to perform in plasma, but is limited by a lack of sensitivity compared to WB ( Boom et al., 2002; Von Müller et al., 2007). PCR amplification of the large and small amplicon of HCMV showed that HCMV DNA highly fragmented in plasma and serum of renal transplant recipients which does not necessarily indicate the amount of infectious virus present (Chen et al., 2014). An 8-fold increase in viral titer was observed with 500 and 4000 copies/ml in plasma and WB, respectively, from a cohort of 82 renal transplant recipients ( Chou et al., 1992; Abedi et al., 2017). A study from UCB of 825 pregnant women reported that the type of blood components can affect the positive rate of HCMV diagnosis given that a higher PCR positive rate for HCMV DNA was found in PBL compared to plasma (Khare et al., 2004). Simultaneous quantification of HCMV load in WB, plasma, PBL, and PBMCs from 319 samples revealed a higher viral load in WB compared to other blood components. Due to the invasive nature of blood collection, some patients might avoid testing. To address this, a group of researchers investigated the use of serial PCR assays on maternal urine samples for HCMV detection. Urine PCR results were compared with cord blood serology results and showed that only 1 out of $609(0.16 \%)$ women had viral DNA in the urine and subsequently developed seroconversion (Khare et al., 2004). Such clinical research indicates that $\mathrm{WB}$ is the favorable specimen compared to serum or plasma due to positive detection, higher viral load, and increased sensitivity for HCMV monitoring.

\subsection{Target sequence selection}

PCR is a rapid, sensitive, and versatile method for HCMV detection that is based on the amplification of nucleic acids and generally targets major immediate-early (MIE) and late antigen genes in well conserved regions 
(Lengerova et al., 2007; Leruez-Ville et al., 2008). Target gene selection can be based on its presence in clinically relevant strains, number of copies present in various species, conserved nature, and growth stages. HCMV is known to be highly divergent in certain coding regions and undergoes frequent recombination (Chou et al., 1992). Due to sequence variability, very few conserved regions, such as MIE (M21295.1), UL54 (DNA polymerase catalytic subunit, AB329634.1), UL55 which encodes glycoprotein B (gB) (U66425.1), UL83 (KJ743149.1) which encodes 65 $\mathrm{kDa}$ phosphoprotein and TRL1/IRL11 (open reading frame), can be exploited as target genes. The gB gene (UL55) is known to contain less variable regions of the HCMV genome, except for two variable subregions (Shepp et al., 1996; Murphy et al., 2003; Li et al., 2003), and has been frequently used as a target for certain PCR assays (Hong et al., 2004; Nye et al., 2005). Despite its conservation, one study reported the failure of $\mathrm{gB}$ region amplification for HCMV quantification in $11 \%$ (6/54) of isolates compared to DNA polymerase region targeting due to sequence diversity in the C630T variant (Habbal et al., 2009). The average variation in viral load was found to be associated with the amplification of target genes used for HCMV detection. Primer sets targeting the $\mathrm{gB}$ region have been reported to show higher sensitivity and specificity for detecting viral DNA from standard strains and clinical isolates than those targeting the UL54, UL83, and TRL11 regions (Enan et al., 2011). In contrast, another study found that primers targeting immediate early and late CMV antigen genes had 93\% sensitivity and $100 \%$ specificity in urine samples from newborns with congenital CMV infection (Demmler, 1991). PCR targeting of a $105 \mathrm{bp}$ region of the MIE gene identified 32 (32.7\%) positive blood samples from 98 renal transplant recipients with viral loads ranging from 200 to 42932 copies/ml, suggesting that the MIE region is a sensitive molecular target for HCMV detection (Hayden et al., 2012). PCR amplification of DNA polymerase for HCMV quantification yielded lower viral load (4.49 $\log _{10}$ ) compared to other target genes: immediate-early $\left(5.16 \log _{10}\right.$; $p<0.0001)$, MIE (4.79 $\left.\log _{10} ; p=0.0269\right)$, and $\mathrm{gB}\left(4.82 \log _{10} ; p=0.0359\right)$ (Zhang et al., 2010). A comparative study focusing on three functionally important and highly conserved CMV genes, DNA polymerase, $\mathrm{gB}$, and the IE1 or MIE region, found that primers targeting the DNA polymerase gene were more sensitive and had less sequence variation for viral DNA detection in 46 isolates than those targeting the MIE region (Tabata et al., 2016). However, a recent study reported the development of an in-house multiplex PCR assay targeting the MIE gene with a lower limit of detection of 150 copies/ml (Duraisamy et al., 2018). These results suggest that targeting the MIE region is a sensitive tool for the quantitative assessment of HCMV in clinical isolates (Tabata et al., 2016; Paul et al., 2018).

\subsection{Selection of PCR approach}

PCR is a rapid, sensitive, and versatile technique to detect HCMV infection. qRT-PCR is typically used considering its superiority in quantifying the viral titer and reducing the probability of contamination through the use of closed system. nPCR utilizes two amplification rounds to significantly increase specificity and sensitivity. However, which is more suitable for HCMV infection monitoring is still under debate given that the results of many appropriate reports are contraindicatory ( Ikewaki et al., 2003; Botero et al., 2008). Zhang et al. (2010) compared two PCR techniques, qPCR and nPCR, for detecting HCMV DNA in 106 blood samples from 66 patients with potential HCMV infections. nPCR demonstrated a higher parasite detection rate than qPCR (34.9\% vs $12.3 \%, p<0.001$ ) and nPCR was found to be the most sensitive method for HCMV detection. However, false positive results caused by cross-contamination remain a major barrier with nPCR. Therefore, one must consider strict adaptation of precautionary measures to limit this (Tabata et al., 2016).

To eliminate the problem of contamination in nPCR, a group of researchers have developed the boosted nPCR. This enables amplification in a single step and thus reduces contamination while achieving a detection limit of $1 \mathrm{fg}$ of HCMV DNA, which corresponds to approximately 70 viral copies (Borg et al., 1995). Real-time PCR assays for quantifying HCMV have traditionally used TaqMan or hybridization probes (Nitsche et al., 1999). TaqMan probes are linear and labelled with a reporter and a quencher dye while molecular beacons are singlestranded oligonucleotide probes with a stem-loop structure. Real-time qPCR assays using TaqMan probes or a molecular beacon were developed for the detection and quantification of EBV and HCMV in blood samples from AIDS patients and both assays were reported to be reliable and reproducible with low interassay and intraassay variation. Moreover, these assays are suitable for routine diagnostic testing, but designing molecular beacons is more time consuming than TaqMan probes (Jebbink et al., 2003). A comparative study between real time qPCR and nPCR for the detection of HSV-1, EBV, and HCMV DNA indicated an overall agreement between the two methods, but one negative sample was found to be positive through real time PCR (Drago et al., 2004).

In contrast, one study reported improved detection of HCMV DNA using nPCR compared to real-time qPCR $(p<0.0001)$ in gingival crevicular fluid from a group of 44 periodontitis patients. The previous study mentioned that LAMP is highly sensitive method with a lower detection limit of 10 copies of HCMV DNA per microliter and has a good correlation with real time qPCR (Reddy et al., 2010). One study, using serially-diluted CMV gB-containing plasmids to determine sensitivity, revealed that greater than 10 copies per reaction were detectable using the HCMV LAMP method on blood and amniotic fluid samples from pregnant women (Wang et al., 2015).

\section{Rubella Virus (RubV)}

\subsection{Specimen selection}

Several sample types, such as WB, plasma, amniotic fluid, and urine, are used for rubella virus RNA detection. However, pharyngeal 
samples, including nasal aspirates and throat swabs (TS), are the preferred specimens for detecting the rubella virus in both acute cases and congenital rubella syndrome (CRS) (Zhou et al., 2007; Yasui et al., 2014). Blood has been suggested not to be a good specimen for RubV detection because the virus remains undetectable in blood for two days after rash onset (Zhu et al., 2007). In contrast, the viral titer in throat swabs peaks on the day of rash onset and declines more slowly than in the blood, enabling virus detection up to five to seven days after rash onset ( Davis et al., 1971; Zhu et al., 2007). However, most published reports have used peripheral blood or serum samples with good sensitivity for rubella RNA detection in pregnant women ( Curti et al., 2014; Zanga et al., 2017). Along with the sample type, collection timing is also a crucial factor. The sample should be collected immediately after symptom onset; between one to three days, but not after seven days, after the onset of symptoms to detect cases of acute rubella. Rubella virus continues to shed up to a year after birth in CRS cases. However, around $50 \%$ of patients will no longer shed virus and thus samples should be collected before 3 months of age (Sugishita et al., 2016).

\subsection{Target selection}

The RubV genome is comprised of less than 10,000 nucleotides which encode five proteins, including three structural proteins, E1, E2, and the capsid protein. The E1 (NC_001545.2) sequence between 8731 and 9469 nucleotide position in the RubV genome is recommended by the WHO as a target site for detection by PCR (WHO, 2005). Bosma et al (1995) first reported primers targeting the E1 open reading frame to be a sensitive and specific strategy for RubV detection by reverse transcription nPCR (RT-PCR). This approach was able to detect two RNA copies from five wild-type rubella strains and four vaccine strains with no nonspecific amplification of 16 other RNA viruses. The complete nucleotide sequence of $\mathrm{E} 1$ in RubV is highly conserved across various wild-type rubella strains and is also likely present in most clinical samples infected by RubV (Dominguez et al., 1990). A number of studies described the phylogenetic analysis of 103 different E1 gene sequences from RubV isolated from 17 countries between 1961 and 2000 and concluded that the E1 gene region was the most highly conserved target among all strains (Katow et al., 1997; Zhou et al., 2007). Many published reports have targeted the E1 open reading frame for qualitative or quantitative determination of RubV from a variety of clinical specimens, including from pregnant women, and described it to be a specific and sensitive approach for molecular assays (Vyse \& Jin, 2002; Lazar et al., 2016).

\subsection{Selection of PCR approach}

Several studies have reported the development of reverse transcription nPCR (RT-nPCR) and qRT-PCR assays for detecting RubV RNA using the oligonucleotide pair targeting a conserved region of the E1 gene (Katow et al., 1997; Zhou et al., 2007). One study reported the positive samples from oral fluid $(13 / 19 ; 68.4 \%)$, throat swabs $(26 / 41$
$63.4 \%)$, and fetal tissue $(2 / 2 ; 100 \%)$ to find a total positive sample rate of $66.0 \%$ using RT-nPCR for detecting rubella virus (Reddy et al., 2010). Others have reported that the optimized nRT-PCR assay was specific and sensitive enough to detect just $10 \mathrm{fg}$ of rubella RNA (Shyamala et al., 2007). Okamoto et al. (2010) developed a high throughput TaqMan based one step real time assay, and its sensitivity was compared to conventional RT-nPCR for the diagnosis of rubella infection. They found the qPCR assay to have a detection limit of 10 copies of rubella RNA and 1 pfu of virus and considered it to be useful for rapid screening and diagnosis of rubella in conjunction with nPCR (Okamoto et al., 2010).

\section{Herpesvirus Family (HSVs \& VZV)}

\subsection{Specimen selection}

Different specimens, such as cerebrospinal fluid (CSF), WB, serum, plasma, and cellular samples including biopsies, swabs, bone marrow etc., are used for the molecular detection of HSVs DNA. Paraffinembedded tissues can be also tested for the presence of virus after deparaffinization. The optimal sample for viral detection depends on the virus and its associated clinical disease. Gestational tissues from 36 women with pregnancy loss were tested for HSV1-2 DNA by nPCR (Kapranos \& Kotronias, 2009). Most reports have mentioned the use of cervical smears (Dinc et al., 2010; Caldeira et al., 2013) and blood (Zhou et al., 2015) samples for HSV1-2 DNA detection in pregnant women using a PCR approach. One group tested WB and serum or plasma specimens from 21 patients with clinical symptoms of varicella and 21 with herpes zoster and reported the lower limit of detection sensitivity to be 20 copies/ml from plasma or serum and 80 copies $/ \mathrm{ml}$ from WB. This shows that the quantification of VZV or HSV DNA in WB has potential for the diagnosis and clinical management of infected patients. In contrast, cell-free plasma and serum provide convenient matrices for this purpose (de Jong et al., 2000). The presence of virus during VZV infections is thought to be highly cell-associated and this has been observed during in vitro growth cycles of the virus. However, the quantification of HSVs viral DNA in blood has been restricted to the analysis of isolated PBMCs (de Jong et al., 2000).

\subsection{Target selection}

Detection of HSV1-2 DNA by PCR is a classical molecular approach routinely performed by numerous clinical laboratories. The similarities and variations between HSV1-2 genomes are utilized for genera specific molecular assays. The $\mathrm{gB}$ and $\mathrm{gD}$ genes are targeted to differentiate HSV1-2, while the DNA polymerase gene is targeted for detecting both serotypes simultaneously (Arvin et al., 1996; LeGoff et al., 2014). The major seven loci, distributed throughout unique long $\left(\mathrm{U}_{\mathrm{L}}\right)$ and unique short $\left(\mathrm{U}_{\mathrm{S}}\right)$ regions of the HSV1-2 genomes, include DNA polymerase (HSV1: X04771.1, HSV 2: M16321.1), gB or UL27 (AF259899.1, AF021340.1), and thymidine kinase (TK) or UL23 (HSV1: AB009254.2, HSV2: AB009257.1) 
genes which are widely reported for the detection of viral DNA in various clinical specimens (LeGoff et al., 2014). The detection of HSVs DNA by targeting the TK gene in CSF samples revealed its highly variable nucleotide sequence. However, analyzing a 335-bp amplicon within the TK gene revealed the presence of 51 nucleotides that are consistently present to enable differentiation between HSV 1-2 (Aslanzadeh et al., 1993; Tang et al., 1999). Unlike TK, the DNA polymerase gene comprises highly conserved region and degenerate primers targeting this region are used to amplify DNA from several species of human and animal HSVs. HSVs DNA quantification by targeting the DNA polymerase gene has been reported to have detection limits of $0.5 \mathrm{fg}$, corresponding to the 3.1 viral particles for HSV-1, and $0.2 \mathrm{fg}$, corresponding to 1.3 viral particles for HSV-2, indicating good sensitivity (Madhavan et al., 1999).

\subsection{Selection of PCR approach}

Qualitative PCR assays, such as nPCR and PCR, along with southern blot hybridization are widely used for the diagnosis of HSV infection. However, quantitative assays based on real time PCR are more recently used to measure the HSV viral load (Kimura et al., 2002). A recent study suggested the nPCR method to be better than the virus culture assay (Dominguez et al., 2018). Kawada et al. compared qPCR with nPCR and reported that realtime qPCR had a specificity of 99\% (137/139) and sensitivity of $100 \%(25 / 25)$ compared with nPCR in detecting 100 copies per ml from CSF samples (Kawada et al., 2004). While testing 110 dermal or genital lesions, the nPCR assay was reported to detect $22 \%$, $37 \%$, and $46 \%$ of samples positive for HSV-1, HSV-2, and VZV, respectively, whereas, qPCR detected $24 \%, 36 \%$, and $46 \%$ of samples positive (Schmutzhard et al., 2004). The testing of 46 samples using nested and real time PCR targeting the gpD region showed the same number of positive samples by both assays; however, one negative sample in nPCR was detected as positive in qPCR. Thus, qPCR demonstrates comparatively higher sensitivity and specificity (Aslanzadeh et al., 1993). A comparative analysis between CPCR and real-time PCR in 147 CSF samples was performed for detection of major neurotropic viruses, i.e., HSV1-2, CMV, VZV, and EBV. Overall, real time PCR yielded 88 (59.9\%) positives while cPCR had only $6(4.1 \%)$, suggesting qPCR is much more sensitive than cPCR (Ramamurthy et al., 2011). A significant $(p<0.05)$ increase in positive samples was detected by real-time qPCR (44\%) compared with (8\%) nPCR (Franzen-Rohl et al., 2007). The lower limit of detection for an in-house developed $\mathrm{nPCR}$ assay was reported to be approximately 5 copies/ $\mu \mathrm{L}$ for HSV and 10 copies/ $\mu \mathrm{L}$ for $\mathrm{VZV}$, indicating high analytical sensitivity (Rodrigues et al., 2013).

\section{Parvovirus B19 (B19V)}

B19V infection during pregnancy can infect the fetal erythroid precursor cells and fetal tissues, which may act as a danger signal for the fetus. B19V is the smallest DNA virus that can be detected in the plasma, serum, peripheral blood, amniotic fluids, and cord blood, and was first identified in the plasma in 2005 by random molecular screening (Allander et al., 2005; Naciute et al., 2016). The two distinct viral proteins, named viral capsid proteins VP1 $(83 \mathrm{kDa})$ and VP2 (58 kDa), and a non-structural (NS1, AY903437.2) protein are encoded by regions widely targeted for B $19 \mathrm{~V}$ detection. Chen et al detected B19V DNA by targeting the VP2 gene and were able to detect as few as five copies of viral DNA per reaction using PCR (Chen et al., 2009). In contrast, several studies have targeted the NS1 region in serum samples of pregnant women and reported it to be a highly specific molecular target for detecting B19V DNA (Shabani et al., 2015; Arabzadeh et al., 2017).

An overview on the molecular detection of TORCH organisms and their target nucleotide sequences for PCR detection is depicted in Figure 1.

\section{Conclusion and Future Directions}

We have evaluated the key factors and variables that can affect the sensitivity and specificity of molecular detection of TORCH organisms. Variation in target genomic sequences, specimen matrix, primer sequences, and modifications to PCR conditions can significantly affect the performance of molecular assays. Despite the broad use of conventional and nested PCR for TORCH detection, their application is limited to only qualitative measures. In contrast, real time PCR provides both qualitative and quantitative measures and increases the limit of detection while reducing the chances of contamination. After analyzing published reports, buffy coat has been found to be a reliable specimen matrix for PCR detection of TORCH organisms. The buffy coat can yield sufficient amounts of DNA, even after extended periods of storage. It offers the advantage of increased numbers of blood cells, and thus, higher copies of the organisms owing to the cell-associated nature of most TORCH organisms. The target genomic sequence should be present in the most conserved regions of all strains and should be in multiple copies to achieve efficient molecular detection. After a thorough review of the published reports, we can understand that genomic regions such as B1, major immediate early region, DNA polymerase, and E1 protein are the ideal targets for efficient detection of toxoplasma, cytomegalovirus, herpesvirus, and rubella, respectively, using PCR assays. The principal factors affecting the molecular detection of each organism of TORCH should be thoroughly understood before applying them for clinical detection. The development of a highly sensitive and specific multiplexed PCR assay to detect all the organisms of TORCH will be a quick and cost-effective approach that should be developed in future. It will be highly useful for screening large numbers of pregnant women in public health studies and suggesting preventive or curative measures. 
TORCH

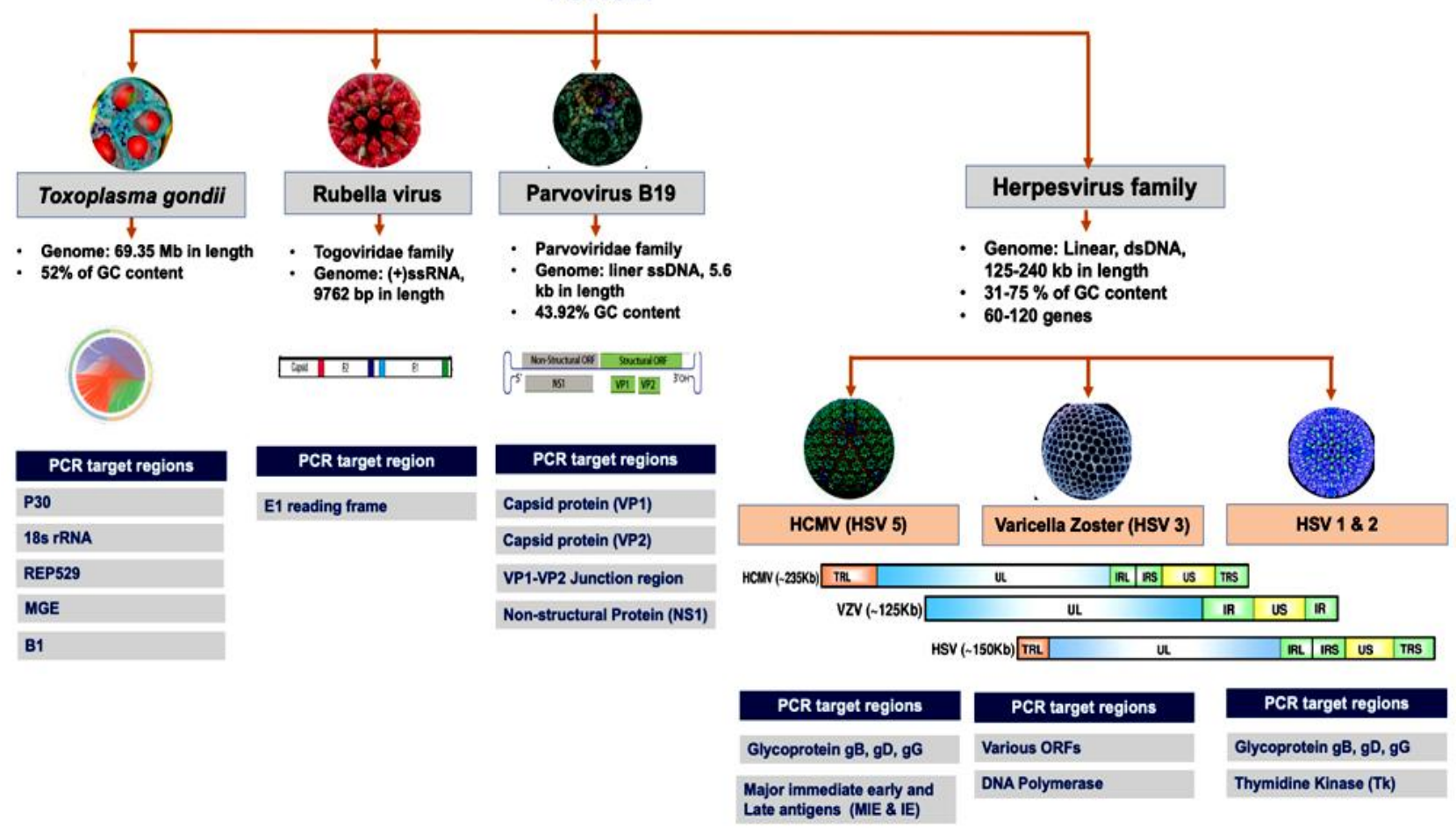

Figure 1: Molecular detection of TORCH complex organisms and their target nucleotide sequences for PCR detection. The figure showing the complete genome structure of TORCH organisms. There are multiple PCR targets such as B1, REP529, P30, 18s rRNA for Toxoplasma; immediate early genes, thymidine kinase, DNA polymerase and various glycoproteins for Herpesvirus family while viral capsid proteins (VP1 and VP2) and non-structural proteins for Parvovirus B19 detection. Rubella virus can be detected by targeting the highly conserved envelope glycoprotein region.

\section{Acknowledgments}

All the authors acknowledge and thank their respective Institutes and Universities.

\section{Author contributions}

All the authors substantially contributed to the conception, compilation of data, checking and approving the final version of the manuscript, and agree to be accountable for its contents.

\section{Conflict of interest}

All authors declare that there exist no commercial or financial relationships that could, in any way, lead to a potential conflict of interest.

\section{Funding}

The review is part of a research project supported by SEED division of Department of Science and Technology, Government of India (Grant No: DST SEED-TIASN-2/002/2014).

\section{References}

Aal AAA, Attia SS, Hanafy NA, Al-Antably AS, Hassan MA, ElSherbiny W, Nasr AS (2014) Molecular Diagnosis of Toxoplasmosis in Non Immune Pregnant Females. Macedonian Journal of Medical Sciences 7(3): 415-420.

Abedi E, Kheirandish M, Sharifi Z, Samiee S, Kokhaei P, Pourpak Z, Ashraf MJ (2017) Quantification of Active and Latent Form of Human Cytomegalovirus Infection in Umbilical Cord Blood Donors by RealTime PCR. International Journal of Organ Transplantation Medicine 8(3): $140-145$.

Ahmadpour E, Zargami E, Mahami-Oskouei M, Spotin A, Shahbazi A, Kafil HS, Rajabi S, Alizadeh P, Azadi Y, Bahaj R (2019) Diagnosis of Toxoplasma gondii infection in pregnant women using automated chemiluminescence and quantitative real time PCR. Asian Pacific Journal of Tropical Medicine 12(1): 26.

Ajzenberg D (2010) Is PCR testing on blood samples useful or not in the diagnosis of Toxoplasma encephalitis? Transactions of the Royal Society of Tropical Medicine and Hygiene 104(8): 569-570.

Journal of Experimental Biology and Agricultural Sciences http://www.jebas.org 
Akane A, Matsubara K, Nakamura H, Takahashi S, Kimura K (1994) Identification of the heme compound copurified with deoxyribonucleic acid (DNA) from bloodstains, a major inhibitor of polymerase chain reaction (PCR) amplification. Journal of Forensic Science 39(2): 362-372.

Al-Hadraawy SK, Hadi FA (2017) Immunological and Molecular Study of Toxoplasma gondii in Al-Najaf Governorate-Iraq International Journal of Pharmacognosy and Phytochemical Research 9(4): 482-492.

Allander T, Tammi MT, Eriksson M, Bjerkner A, Tiveljung-Lindell A, Andersson B (2005) Cloning of a human parvovirus by molecular screening of respiratory tract samples. Proceedings of the National Academy of Sciences of the United States of America 102(36): 1289112896.

Arabzadeh SA, Alizadeh F, Tavakoli A, Mollaei H, Bokharaei-Salim F, Karimi G, Farahmand M, Mortazavi HS, Monavari SH (2017) Human parvovirus B19 in patients with beta thalassemia major from Tehran, Iran. Blood Research 52(1): 50-54.

Arora N, Novak Z, Fowler KB, Boppana SB, Ross SA (2010) Cytomegalovirus viruria and DNAemia in healthy seropositive women. Journal of Infectious Diseases 202(12): 1800-1803.

Arvin AM, Moffat JF, Redman R (1996) Varicella-zoster virus: aspects of pathogenesis and host response to natural infection and varicella vaccine. Advances in Virus Research 46: 263-309.

Aslanzadeh J, Garner JG, Feder HM, Ryan RW (1993) Use of polymerase chain reaction for laboratory diagnosis of herpes simplex virus encephalitis. Annals of Clinical \& Laboratory Science 23(3): 196-202.

Belaz S, Gangneux JP, Dupretz P, Guiguen C, Robert-Gangneux F (2015) A 10-year retrospective comparison of two target sequences, REP-529 and B1, for Toxoplasma gondii detection by quantitative PCR. Journal of Clinical Microbiology 53(4): 1294-1300.

Bin Dajem SM, Almushait MA (2012) Detection of Toxoplasma gondii DNA by PCR in blood samples collected from pregnant Saudi women from the Aseer region, Saudi Arabia. Annals of Saudi Medicine 32(5): 507-512.

Boom R, Sol CJA, Schuurman T, van Breda A, Weel JFL, Beld M, ten Berge IJM, Wertheim-van Dillen PME, de Jong MD (2002) Human cytomegalovirus DNA in plasma and serum specimens of renal transplant recipients is highly fragmented. Journal of Clinical Microbiology 40(11): 4105-4113.

Borg KL, Nordbø SA, Winge P, Dalen A (1995) Detection of cytomegalovirus using 'boosted'nested PCR. Molecular and Cellular Probes 9(4): 251-257.
Bosma TJ, Corbett KM, O'Shea S, Banatvala JE, Best JM (1995) PCR for detection of rubella virus RNA in clinical samples. Journal of Clinical Microbiology 33(5): 1075-1079.

Botero JE, Vidal C, Contreras A, Parra B (2008) Comparison of nested polymerase chain reaction (PCR), real-time PCR and viral culture for the detection of cytomegalovirus in subgingival samples. Oral Microbiology and Immunology 23(3): 239-244.

Bourdin C, Busse A, Kouamou E, Touafek F, Bodaghi B, Le Hoang P, Mazier D, Paris L, Fekkar A (2014) PCR-based detection of Toxoplasma gondii DNA in blood and ocular samples for diagnosis of ocular toxoplasmosis. Journal of Clinical Microbiology 52(11): 39873991.

Brenier-Pinchart MP, Capderou E, Bertini RL, Bailly S, FrickerHidalgo H, Varlet-Marie E, Murat JB, Sterkers Y, Touafek F, Bastien P, Pelloux H (2015) Molecular diagnosis of toxoplasmosis: value of the buffy coat for the detection of circulating Toxoplasma gondii. Diagnostic Microbiology and Infectious Disease 82(4): 289-291.

Burg JL, Grover CM, Pouletty P, Boothroyd JC (1989) Direct and sensitive detection of a pathogenic protozoan, Toxoplasma gondii, by polymerase chain reaction. Journal of Clinical Microbiology 27(8): 1787-1792.

Caldeira TDM, Goncalves CV, Oliveira GRd, Fonseca TVd, Goncalves R, Amaral CTd, Hora VPd, Martinez AMBd (2013) Prevalence of herpes simplex virus type 2 and risk factors associated with this infection in women in southern Brazil. Journal of Revista do Instituto de Medicina Tropical de São Paulo 55(5): 315-321.

Cannon MJ, Westbrook K, Levis D, Schleiss MR, Thackeray, Pass RF (2012) Awareness of and behaviors related to child-to-mother transmission of cytomegalovirus. Preventive Medicine 54(5): 351-357.

Cardona N, Basto N, Parra B, Zea AF, Pardo CA, Bonelo A, GómezMarin JE (2011) Detection of Toxoplasma DNA in the peripheral blood of HIV-positive patients with neuro-opportunistic infections by a real-time PCR assay. Journal of Neuroinfectious Diseases 2. doi:10.4303/jnp/N110402.

Cassaing S, Bessières MH, Berry A, Berrebi A, Fabre R, Magnaval JF (2006) Comparison between two amplification sets for molecular diagnosis of toxoplasmosis by real-time PCR. Journal of Clinical Microbiology 44(3): 720-724.

Cermakova Z, Ryskova O, Pliskova L (2005) Polymerase chain reaction for detection of Toxoplasma gondii in human biological samples. Folia Microbiologica 50(4): 341-344.

Chen XY, Hou PF, Bi J, Ying CM (2014) Detection of human cytomegalovirus DNA in various blood components after liver 
transplantation. Brazilian Journal of Medical and Biological Research 47(4): 340-344.

Chen Z, Guan W, Cheng F, Chen AY, Qiu J (2009) Molecular characterization of human parvovirus B19 genotypes 2 and 3. Virology 394(2): 276-285.

Chou Q, Russell M, Birch DE, Raymond J, Bloch W (1992) Prevention of pre-PCR mis-priming and primer dimerization improves low-copynumber amplifications. Nucleic Acids Research 20(7): 1717-1723.

Cofre F, Delpiano L, Labrana Y, Reyes A, Sandoval A, Izquierdo G (2016) [TORCH syndrome: Rational approach of pre and post natal diagnosis and treatment. Recommendations of the Advisory Committee on Neonatal Infections Sociedad Chilena de Infectologia, 2016]. Revista chilena de infectología 33(2): 191-216.

Contini C, Giuliodori M, Cultrera R, Seraceni S (2006) Detection of clinical-stage specific molecular Toxoplasma gondii gene patterns in patients with toxoplasmic lymphadenitis. Journal of Medical Microbiology 55(Pt 6): 771-774.

Correia CC, Melo HRL, Costa VMA (2010) Influence of neurotoxoplasmosis characteristics on real-time PCR sensitivity among AIDS patients in Brazil. Transactions of the Royal Society of Tropical Medicine and Hygiene 104(1): 24-28.

Costa ME, Oliveira CB, Andrade JM, Medeiros TA, Neto VF, Lanza DC (2016) An alternative nested-PCR assay for the detection of Toxoplasma gondii strains based on GRA7 gene sequences. Acta Tropica 159: 120-124.

Cristina N, Derouin F, Pelloux H, Pierce R, Cesbron-Delauwn MF Ambroise-Thomas P (1992) Detection of Toxoplasma gondii by" Polymerase Chain Reaction"(PCR) technique in AIDS infected patients using the repetitive sequence TGR1E. Pathologie-Biologie 40(1): 52 55 .

Curti SP, Figueiredo CA, Oliveira MId, Andrade JQ, Zugaib M, Pedreira DAL, Durigon EL (2014) Prenatal diagnosis of congenita rubella infection in São Paulo. Revista da Associação Médica Brasileira Journal 60(5): 451-456.

Davis WJ, Larson HE, Simsarian JP, Parkman PD, Meyer HM, Jr. (1971) A study of rubella immunity and resistance to infection. JAMA 215(4): 600-608

de Jong MD, Weel JF, Schuurman T, Wertheim-van Dillen PM, Boom R (2000) Quantitation of varicella-zoster virus DNA in whole blood, plasma, and serum by PCR and electrochemiluminescence. Journal of Clinical Microbiology 38(7): 2568-2573.

Deback C, Fillet AM, Dhedin N, Barrou B, Varnous S, Najioullah F, Bricaire F, Agut H (2007) Monitoring of human cytomegalovirus infection in immunosuppressed patients using real-time PCR on whole blood. Journal of clinical virology 40(3): 173-179.

Demmler GJ (1991) Infectious Diseases Society of America and Centers for Disease Control. Summary of a workshop on surveillance for congenital cytomegalovirus disease. Reviews of Infectious Diseases 13(2): 315-329.

Dinc B, Bozdayi G, Biri A, Kalkanci A, Dogan B, Bozkurt N, Rota S (2010) Molecular detection of cytomegalovirus, herpes simplex virus 2, human papillomavirus 16-18 in Turkish pregnants. Brazilian Journal of Infectious Diseases 14(6): 569-574.

Djurkovic-Djakovic O, Djokic V, Vujanic M, Zivkovic T, Bobic B, Nikolic A, Slavic K, Klun I, Ivovic V (2012) Kinetics of parasite burdens in blood and tissues during murine toxoplasmosis. Experimental Parasitology 131(3): 372-376.

Dollard SC, Grosse SD, Ross DS (2007) New estimates of the prevalence of neurological and sensory sequelae and mortality associated with congenital cytomegalovirus infection. Reviews in Medical Virology 17(5): 355-363.

Dominguez G, Wang CY, Frey TK (1990) Sequence of the genome RNA of rubella virus: evidence for genetic rearrangement during togavirus evolution. Virology 177(1): 225-238.

Dominguez SR, Pretty K, Hengartner R, Robinson CC (2018) Comparison of Herpes Simplex Virus PCR with Culture for Virus Detection in Multisource Surface Swab Specimens from Neonates. Journal of Clinical Microbiology 56(10).

Drago L, Lombardi A, De Vecchi E, Giuliani G, Bartolone R, Gismondo MR (2004) Comparison of nested PCR and real time PCR of Herpesvirus infections of central nervous system in HIV patients. BMC Infectious Diseases 4: 55.

Dupon M, Cazenave J, Pellegrin JL, Ragnaud JM, Cheyrou A, Fischer I, Leng B, Lacut JY (1995) Detection of Toxoplasma gondii by PCR and tissue culture in cerebrospinal fluid and blood of human immunodeficiency virus-seropositive patients. Journal of Clinical Microbiology 33(9): 2421-2426.

Duraisamy SK, Mammen S, Lakshminarayan SKR, Verghese S, Moorthy M, George B, Kannangai R, Varghese S, Srivastava A, Abraham AM (2018) Performance of an in-house real-time PCR assay for detecting Cytomegalovirus infection among transplant patients from a tertiary care centre. Indian Journal of Medical Microbiology 36(2): 241.

Edvinsson B, Lappalainen M, Evengard B (2006) Real-time PCR targeting a 529-bp repeat element for diagnosis of toxoplasmosis. Clinical Microbiology and Infection 12(2): 131-136. 
Emna S, Karim A, Mohamed KC, Aida B (2006) [Difficulty in dating primary infections by Toxoplasma gondii in pregnant women in Tunisia]. Tunis Medicine 84(2): 85-87.

Enan KA, Rennert H, El-Eragi AM, El Hussein AR, Elkhidir IM (2011) Comparison of Real-time PCR to ELISA for the detection of human cytomegalovirus infection in renal transplant patients in the Sudan. Virology Journal 8: 222.

Fabbri E, Revello MG, Furione M, Zavattoni M, Lilleri D, Tassis B, Quarenghi A, Rustico M, Nicolini U, Ferrazzi E, Gerna G (2011) Prognostic markers of symptomatic congenital human cytomegalovirus infection in fetal blood. BJOG 118(4): 448-456.

Fallahi S, Kazemi B, Seyyed tabaei SJ, Bandehpour M, Lasjerdi Z, Taghipour N, Zebardast N, Nikmanesh B, Omrani VF, Ebrahimzadeh F (2014) Comparison of the RE and B1 gene for detection of Toxoplasma gondii infection in children with cancer. Parasitology International 63(1): 37-41

Franzen-Rohl E, Tiveljung-Lindell A, Grillner L, Aurelius E (2007) Increased detection rate in diagnosis of herpes simplex virus type 2 meningitis by real-time PCR using cerebrospinal fluid samples. Journal of Clinical Microbiology 45(8): 2516-2520.

Garrigue I, Doussau A, Asselineau J, Bricout H, Couzi L, Rio C, Merville P, Fleury H, Lafon ME, Thiebaut R (2008) Prediction of cytomegalovirus (CMV) plasma load from evaluation of CMV wholeblood load in samples from renal transplant recipients. Journal of Clinical Microbiology 46(2): 493-498.

Habbal W, Monem F, Gartner BC (2009) Comparative evaluation of published cytomegalovirus primers for rapid real-time PCR: which are the most sensitive? Journal of Medical Microbiology 58(Pt 7): 878-883.

Hayden RT, Yan X, Wick MT, Rodriguez AB, Xiong X, Ginocchio CC, Mitchell MJ, Caliendo AM, College of American Pathologists Microbiology Resource C (2012) Factors contributing to variability of quantitative viral PCR results in proficiency testing samples: a multivariate analysis. Journal of Clinical Microbiology 50(2): 337-345.

Homan WL, Vercammen M, De Braekeleer J, Verschueren H (2000) Identification of a 200-to 300-fold repetitive 529 bp DNA fragment in Toxoplasma gondii, and its use for diagnostic and quantitative PCR. International Journal for Parasitology 30(1): 69-75.

Hong KM, Najjar H, Hawley M, Press RD (2004) Quantitative realtime PCR with automated sample preparation for diagnosis and monitoring of cytomegalovirus infection in bone marrow transplant patients. Clinical Chemistry 50(5): 846-856.

Howe DK, Sibley LD (1995) Toxoplasma gondii comprises three clonal lineages: correlation of parasite genotype with human disease. Journal of Infectious Diseases 172(6): 1561-1566.
Ikewaki J, Ohtsuka E, Kawano R, Ogata M, Kikuchi H, Nasu M (2003) Real-time PCR assay compared to nested PCR and antigenemia assays for detecting cytomegalovirus reactivation in adult T-cell leukemialymphoma patients. Journal of clinical Microbiology 41(9): 4382-4387.

Jauregui LH, Higgins J, Zarlenga D, Dubey JP, Lunney JK (2001) Development of a real-time PCR assay for detection of Toxoplasma gondii in pig and mouse tissues. Journal of Clinical Microbiology 39(6): 2065-2071.

Jebbink J, Bai X, Rogers BB, Dawson DB, Scheuermann RH, DomiatiSaad R (2003) Development of real-time PCR assays for the quantitative detection of Epstein-Barr virus and cytomegalovirus, comparison of TaqMan probes, and molecular beacons. Journal of Molecular Diagnostics 5(1): 15-20.

Jones CD, Okhravi N, Adamson P, Tasker S, Lightman S (2000) Comparison of PCR detection methods for B1, P30, and 18S rDNA genes of T. gondii in aqueous humor. Investigative Ophthalmology \& Visual Science 41(3): 634-644.

Kaneko M, Sameshima H, Ikenoue T, Minematsu T (2006) A two-step strategy for detecting intrauterine cytomegalovirus infection with clinical manifestations in the mother, fetus, and newborn. Japanese Journal of Infectious Diseases 59(6): 363-366.

Kapranos NC, Kotronias DC (2009) Detection of herpes simplex virus in first trimester pregnancy loss using molecular techniques. In vivo 23(5): 839-842.

Katow S, Minahara H, Fukushima M, Yamaguchi Y (1997) Molecular epidemiology of rubella by nucleotide sequences of the rubella virus E1 gene in three East Asian countries. Journal of Infectious Diseases 176(3): 602-616.

Kawada J, Kimura H, Ito Y, Hoshino Y, Tanaka-Kitajima N, Ando Y, Futamura M, Morishima T (2004) Comparison of real-time and nested PCR assays for detection of herpes simplex virus DNA. Microbiology and Immunology 48(5): 411-415.

Khalifa Ke-S, Roth A, Roth B, Arasteh KN, Janitschke K (1994) Value of PCR for evaluating occurrence of parasitemia in immunocompromised patients with cerebral and extracerebral toxoplasmosis. Journal of Clinical Microbiology 32(11): 2813-2819.

Khare M, Sharland M, Manyonda I, Rice P, Bland JM, Griffiths P (2004) Use of serial maternal urine cytomegalovirus PCR to detect primary CMV infection in seronegative pregnant women. Journal of Virological Methods 119(1): 31-35.

Kimura H, Ito Y, Futamura M, Ando Y, Yabuta Y, Hoshino Y, Nishiyama Y, Morishima T (2002) Quantitation of viral load in 
neonatal herpes simplex virus infection and comparison between type 1 and type 2. Journal of Medical Virology 67(3): 349-353.

Lamoril J, Molina JM, de Gouvello A, Garin YJ, Deybach JC, Modai J, Derouin F (1996) Detection by PCR of Toxoplasma gondii in blood in the diagnosis of cerebral toxoplasmosis in patients with AIDS. Journal of Clinical Pathology 49(1): 89-92.

Lau YL, Meganathan P, Sonaimuthu P, Thiruvengadam G, Nissapatorn V, Chen Y (2010) Specific, sensitive, and rapid diagnosis of active toxoplasmosis by a loop-mediated isothermal amplification method using blood samples from patients. Journal of Clinical Microbiology 48(10): 3698-3702.

Lavrard I, Chouaid C, Roux P, Poirot JL, Marteau M, Lemarchand B, Meyohas MC, Olivier JL (1995) Pulmonary toxoplasmosis in HIVinfected patients: usefulness of polymerase chain reaction and cell culture. European Respiratory Journal 8(5): 697-700.

Lazar M, Abernathy E, Chen MH, Icenogle J, Janta D, Stanescu A, Pistol A, Santibanez S, Mankertz A, Hubschen JM, Mihaescu G, Necula G, Lupulescu E (2016) Epidemiological and Molecular investigation of a rubella outbreak, Romania, 2011 to 2012. Eurosurveillance 21(38).

LeGoff J, Pere H, Belec L (2014) Diagnosis of genital herpes simplex virus infection in the clinical laboratory. Virology Journal 11: 83.

Lengerova M, Racil Z, Volfova P, Lochmanova J, Berkovcova J, Dvorakova D, Vorlicek J, Mayer J (2007) Real-time PCR diagnostics failure caused by nucleotide variability within exon 4 of the human cytomegalovirus major immediate-early gene. Journal of Clinical Microbiology 45(3): 1042-1044.

Leruez-Ville M, Ducroux A, Rouzioux C (2008) Exon 4 of the human cytomegalovirus (CMV) major immediate-early gene as a target for CMV real-time PCR. Journal of Clinical Microbiology 46(4): 1571-1572.

Li H, Dummer JS, Estes WR, Meng S, Wright PF, Tang YW (2003) Measurement of human cytomegalovirus loads by quantitative realtime PCR for monitoring clinical intervention in transplant recipients. Journal of Clinical Microbiology 41(1): 187-191.

Loens K, Bergs K, Ursi D, Goossens H, Ieven M (2007) Evaluation of NucliSens easyMAG for automated nucleic acid extraction from various clinical specimens. Journal of Clinical Microbiology 45(2): 421-425.

Lorenz TC (2012) Polymerase chain reaction: basic protocol plus troubleshooting and optimization strategies. Journal of Visualized Experiments (63): 3998. doi: 10.3791/3998.

Madhavan HN, Priya K, Anand AR, Therese KL (1999) Detection of herpes simplex virus (HSV) genome using polymerase chain reaction (PCR) in clinical samples comparison of PCR with standard laboratory methods for the detection of HSV. Journal of Clinical Virology 14(2): 145-151.

Madrid L, Varo R, Maculuve S, Nhampossa T, Munoz-Almagro C, Calderon EJ, Esteva C, Carrilho C, Ismail M, Vieites B, Friaza V, Lozano-Dominguez MDC, Menendez C, Bassat Q (2018) Congenital cytomegalovirus, parvovirus and enterovirus infection in Mozambican newborns at birth: A cross-sectional survey. PLoS One 13(3): e0194186.

Martin Ramirez A, Cardenoso Domingo L, Gonzalez Guijarro JJ (2019) PCR Multiplex for CMV Detection in Patients with Anterior Uveitis. Ocular Immunology Inflammation 27(2): 197-202.

Mesquita RT, Ziegler AP, Hiramoto RM, Vidal JE, Pereira-Chioccola VL (2010) Real-time quantitative PCR in cerebral toxoplasmosis diagnosis of Brazilian human immunodeficiency virus-infected patients. Journal of Medical Microbiology 59(Pt 6): 641-647.

Montoya JG, Liesenfeld O, Kinney S, Press C, Remington JS (2002) VIDAS test for avidity of Toxoplasma-specific immunoglobulin $\mathrm{G}$ for confirmatory testing of pregnant women. Journal of Clinical Microbiology 40(7): 2504-2508.

Mousavi M, Saravani R, Modrek MJ, Shahrakipour M, Sekandarpour S (2016) Detection of toxoplasma gondii in diabetic patients using the nested PCR assay via RE and B1 genes. Jundishapur Journal of Microbiology 9(2):e29493. doi: 10.5812/jjm.29493.

Munro SC, Hall B, Whybin LR, Leader L, Robertson P, Maine GT, Rawlinson WD (2005) Diagnosis of and screening for cytomegalovirus infection in pregnant women. Journal of Clinical Microbiology 43(9): 4713-4718.

Murphy E, Yu D, Grimwood J, Schmutz J, Dickson M, Jarvis MA, Hahn G, Nelson JA, Myers RM, Shenk TE (2003) Coding potential of laboratory and clinical strains of human cytomegalovirus. Proceedings of the National Academy of Sciences of the United States of America 100(25): 14976-14981.

Naciute M, Mieliauskaite D, Rugiene R, Nikitenkiene R, Jancoriene L, Mauricas M, Nora-Krukle Z, Murovska M, Girkontaite I (2016) Frequency and significance of parvovirus B19 infection in patients with rheumatoid arthritis. Journa; of General Virology 97(12): 3302-3312.

Nagamine K, Hase T, Notomi T (2002) Accelerated reaction by loop mediated isothermal amplification using loop primers. Molecular and Cellular Probes 16: 223-229.

Nagy B, Ban Z, Beke A, Nagy GR, Lazar L, Papp C, Toth-Pal E, Papp Z (2006) Detection of Toxoplasma gondii from amniotic fluid, a comparison of four different molecular biological methods. Clinica Chimica Acta 368(1-2): 131-137. 
Neu N, Duchon J, Zachariah P (2015) TORCH infections. Clinics in Perinatology 42(1): 77-103, viii.

Nimri L, Pelloux H, Elkhatib L (2004) Detection of Toxoplasma gondii DNA and specific antibodies in high-risk pregnant women. Amecial Journal of Tropical Medicine and Hygiene 71(6): 831-835.

Nitsche A, Steuer N, Schmidt CA, Landt O, Siegert W (1999) Different real-time PCR formats compared for the quantitative detection of human cytomegalovirus DNA. Clinical Chemistry 45(11): 1932-1937.

Nye MB, Leman AR, Meyer ME, Menegus MA, Rothberg PG (2005) Sequence diversity in the glycoprotein B gene complicates real-time PCR assays for detection and quantification of cytomegalovirus. Journal of Clinical Microbiology 43(10): 4968-4971.

Okamoto K, Fujii K, Komase K (2010) Development of a novel TaqMan real-time PCR assay for detecting rubella virus RNA. Journal of Virological Methods 168(1-2): 267-271.

Ossorio PN, Sibley LD, Boothroyd JC (1991) Mitochondrial-like DNA sequences flanked by direct and inverted repeats in the nuclear genome of Toxoplasma gondii. Journal of Molecular Biology 222(3): 525-536.

Paiva-Cavalcanti M, Regis-da-Silva C, Gomes Y (2010) Comparison of real-time PCR and conventional PCR for detection of Leishmania (Leishmania) infantum infection: a mini-review. Journal of Venomous Animals and Toxins including Tropical Diseases 16(4): 537-542.

Paul M, Gupta E, Jain P, Rastogi A, Bhatia V (2018) Diagnostic utility of quantitative cytomegalovirus DNA polymerase chain reaction in intestinal biopsies from patients with inflammatory bowel disease.Journal of Laboratory Physicians 10(1): 38-43.

Pereira-Chioccola VL, Vidal JE, Su C (2009) Toxoplasma gondii infection and cerebral toxoplasmosis in HIV-infected patients. Future Microbiology 4(10): 1363-1379.

Petrik J (2001) Microarray technology: the future of blood testing? Vox Sanguinis 80(1): 1-11.

Prasoona KR, Srinadh B, Sunitha T, Sujatha M, Deepika ML, Vijaya Lakshmi B, Ramaiah A, Jyothy A (2015) Seroprevalence and Influence of Torch Infections in High Risk Pregnant Women: A Large Study from South India. The Journal of Obstetrics and Gynecology of India 65(5): 301-309.

Rajendran C, Keerthana CM, Anilakumar KR, Satbige AS, Gopal S (2018) Development of B1 Nested PCR for Assessing the Prevalence of Zoonotic Protozoan Disease Agent Toxoplasma Gondii among Food Animals from Karnataka State, Southern India. Journal of Microbiology and Laboratory science 1: 101 Abstract Keywords B 1.
Ramamurthy M, Alexander M, Aaron S, Kannangai R, Ravi V, Sridharan G, Abraham AM (2011) Comparison of a conventional polymerase chain reaction with real-time polymerase chain reaction for the detection of neurotropic viruses in cerebrospinal fluid samples.Indian Journal of Medical Microbiology 29(2): 102-109.

Razonable RR, Brown RA, Espy MJ, Rivero A, Kremers W, Wilson J, Groettum C, Smith TF, Paya CV (2001) Comparative quantitation of cytomegalovirus (CMV) DNA in solid organ transplant recipients with CMV infection by using two high-throughput automated systems. Journal of Clinical Microbiology 39(12): 4472-4476.

Reddy AK, Balne PK, Reddy RK, Mathai A, Kaur I (2010) Development and evaluation of loop-mediated isothermal amplification assay for rapid and inexpensive detection of cytomegalovirus DNA in vitreous specimens from suspected cases of viral retinitis. Journal of Clinical Microbiology 48(6): 2050-2052.

Reischl U, Bretagne S, Krüger D, Ernault P, Costa JM (2003) Comparison of two DNA targets for the diagnosis of Toxoplasmosis by real-time PCR using fluorescence resonance energy transfer hybridization probes. BMC infectious diseases 3(1): 7.

Revello MG, Fabbri E, Furione M, Zavattoni M, Lilleri D, Tassis B, Quarenghi A, Cena C, Arossa A, Montanari L, Rognoni V, Spinillo A, Gerna G (2011) Role of prenatal diagnosis and counseling in the management of 735 pregnancies complicated by primary human cytomegalovirus infection: a 20-year experience. Journal of Clinical Virology 50(4): 303-307.

Rinder H, Thomschke A, Dardé ML, Löscher T (1995) Specific DNA polymorphisms discriminate between virulence and non-virulence to mice in nine Toxoplasma gondii strains. Molecular and Biochemical Parasitology 69(1): 123-126.

Robert F, Ouatas T, Blanche P, Tourte-Schaefer C, Sicard D, DupouyCamet J (1996) [Retrospective evaluation of the detection of Toxoplasma gondii by polymerase chain reaction in AIDS patients]. La Presse médicale 25(11): 541-545.

Robert-Gangneux F, Sterkers Y, Yera H, Accoceberry I, Menotti J, Cassaing S, Brenier-Pinchart MP, Hennequin C, Delhaes L, Bonhomme J, Villena I, Scherer E, Dalle F, Touafek F, Filisetti D, Varlet-Marie E, Pelloux H, Bastien P (2015) Molecular diagnosis of toxoplasmosis in immunocompromised patients: a 3-year multicenter retrospective study. Journal of Clinical Microbiology 53(5): 16771684.

Rodrigues D, de-Paris F, Paiva RM (2013) Minimum detection limit of an in-house nested-PCR assay for herpes simplex virus and varicella zoster virus. Journal of the Brazilian Society of Tropical Medicine 46(5): $625-628$. 
Romand S, Wallon M, Franck J, Thulliez P, Peyron F, Dumon H (2001) Prenatal diagnosis using polymerase chain reaction on amniotic fluid for congenital toxoplasmosis. Obstetrics \& Gynecology 97(2): 296-300

Ross SA, Novak Z, Pati S, Boppana SB (2011) Overview of the diagnosis of cytomegalovirus infection. Infectious Disorders - Drug Targets 11(5): 466-474.

Schmutzhard J, Merete Riedel H, Zweygberg Wirgart B, Grillner L (2004) Detection of herpes simplex virus type 1, herpes simplex virus type 2 and varicella-zoster virus in skin lesions. Comparison of realtime PCR, nested PCR and virus isolation. Journal of Clinical Virology 29(2): 120-126.

Sen MR, Shukla BN, Tuhina B (2012) Prevalence of Serum Antibodies to TORCH Infection in and Around Varanasi, Northern India. Journal of Clinical and Diagnostic Research 6(9): 1483-1485.

Shabani Z, Esghaei M, Keyvani H, Shabani F, Sarmadi F, Mollaie H, Monavari SH (2015) Relation between parvovirus B19 infection and fetal mortality and spontaneous abortion. Medical journal of the Islamic Republic of Iran 29: 197.

Shen CY, Chang SF, Yen MS, Ng HT, Huang ES , Wu CW (1993) Cytomegalovirus excretion in pregnant and nonpregnant women. Journal of Clinical Microbiology 31(6): 1635-1636.

Shepp DH, Match ME, Ashraf AB, Lipson SM, Millan C, Pergolizzi R (1996) Cytomegalovirus glycoprotein B groups associated with retinitis in AIDS. Journal of Infectious Diseases 174(1): 184-187.

Shyamala G, Malathi J, Moses YS, Therese KL, Madhavan HN (2007) Nested reverse transcription polymerase chain reaction for the detection of rubella virus in clinical specimens. Indian Journal of Medical Research 125(1): 73-78.

Sterkers Y, Varlet-Marie E, Cassaing S, Brenier-Pinchart MP, Brun S, Dalle F, Delhaes L, Filisetti D, Pelloux H, Yera H, Bastien P (2010) Multicentric comparative analytical performance study for molecular detection of low amounts of Toxoplasma gondii from simulated specimens. Journal of Clinical Microbiology 48(9): 3216-3222.

Su C, Shwab EK, Zhou P, Zhu XQ, Dubey JP (2010) Moving towards an integrated approach to molecular detection and identification of Toxoplasma gondii. Parasitology 137(1): 1-11.

Sugishita Y, Akiba T, Sumitomo M, Hayata N, Hasegawa M, Tsunoda T, Okazaki T, Murauchi K, Hayashi Y, Kai A (2016) Shedding of rubella virus among infants with congenital rubella syndrome born in Tokyo, Japan, 2013-2014. Japanese Journal of Infectious Diseases 69(5): 418-423.

Suviriyapaisal C, Wanachiwanawin D, Limawongpranee S (2017) detection of toxoplasma gondii by per and quantitative per with high specificty and lower limit of detection. The Southeast Asian Journal of Tropical Medicine and Public Health 48(4): 749-755.

Tabata T, Petitt M, Fang-Hoover J, Zydek M, Pereira L (2016) Persistent Cytomegalovirus Infection in Amniotic Membranes of the Human Placenta. The American Journal of Pathology 186(11): 29702986.

Tang YW, Mitchell PS, Espy MJ, Smith TF, Persing DH (1999) Molecular diagnosis of herpes simplex virus infections in the central nervous system. Journal of Clinical Microbiology 37(7): 2127-2136.

Teixeira LE, Kanunfre KA, Shimokawa PT, Targa LS, Rodrigues JC, Domingues W, Yamamoto L, Okay TS (2013) The performance of four molecular methods for the laboratory diagnosis of congenital toxoplasmosis in amniotic fluid samples. Journal of the Brazilian Society of Tropical Medicine 46(5): 584-588.

Varlet-Marie E, Sterkers Y, Brenier-Pinchart MP, Cassaing S, Dalle F, Delhaes L, Filisetti D, Pelloux H, Touafek F, Yera H, Bastien P (2014) Characterization and multicentric validation of a common standard for Toxoplasma gondii detection using nucleic acid amplification assays. Journal of Clinical Microbiology 52(11): 3952-3959.

Veronesi F, Santoro A, Milardi GL, Diaferia M, Branciari R, Miraglia D, Cioffi A, Gabrielli S, Ranucci D (2017) Comparison of PCR assays targeting the multi-copy targets B1 gene and 529 bp repetitive element for detection of Toxoplasma gondii in swine muscle. Food Microbiology 63: 213-216.

Von Müller L, Hinz J, Bommer M, Hampl W, Kluwick S, Wiedmann M, Bunjes D, Mertens T (2007) CMV monitoring using blood cells and plasma: a comparison of apples with oranges? Bone Marrow Transplantation 39(6): 353-357.

Vyse AJ, Jin L (2002) An RT-PCR assay using oral fluid samples to detect rubella virus genome for epidemiological surveillance. Molecular and Cellular Probes 16(2): 93-97.

Wahab T, Edvinsson B, Palm D, Lindh J (2010) Comparison of the AF146527 and B1 repeated elements, two real-time PCR targets used for detection of Toxoplasma gondii. Journal of Clinical Microbiology 48(2): 591-592.

Wang X, Li X, Hu S, Qu H, Zhang Y, Ni H, Wang X (2015) Rapid detection of active human cytomegalovirus infection in pregnancy using loop-mediated isothermal amplification. Molecular Medicine Reports 12(2): 2269-2274.

Wang Y, Yin H (2014) Research progress on surface antigen 1 (SAG1) of Toxoplasma gondii. Parasites \& Vectors 7: 180.

Wells B, Shaw H, Innocent G, Guido S, Hotchkiss E, Parigi M, Opsteegh M, Green J, Gillespie S, Innes EA, Katzer F (2015) 
Molecular detection of Toxoplasma gondii in water samples from Scotland and a comparison between the 529bp real-time PCR and ITS 1 nested PCR. Water Research 87: 175-181.

WHO (2005) Standardization of the nomenclature for genetic characteristics of wild-type rubella viruses. The Weekly Epidemiological Record 80(14): 126-132.

Yadav RK, Maity S, Saha S (2014) A review on TORCH: groups of congenital infection during pregnancy. Journal of Sceintific Research 3(2): 258-264.

Yasui Y, Mori Y, Adachi H, Kobayashi S, Yamashita T, Minagawa H (2014) Detection and genotyping of rubella virus from exanthematous patients suspected of having measles using reverse transcription-PCR. Japanese Journal of Infectious Diseases 67(5): 389-391.

Yerly S, Perrin L, Van Delden C, Schaffer S, Thamm S, Wunderli W, Kaiser L (2007) Cytomegalovirus quantification in plasma by an automated real-time PCR assay. Journal of Clinical Virology 38(4): 298-303.

Zanga J, Mbanzulu MK, Kabasele A-F, Ngatu NR, Wumba DR (2017) Rubella Seroprevalence and real-time PCR detection of RUBV among
Congolese pregnant women. BMC infectious diseases 17(1): 250.

Zhang H, Thekisoe OM, Aboge GO, Kyan H, Yamagishi J, Inoue N, Nishikawa Y, Zakimi S, Xuan X (2009) Toxoplasma gondii: sensitive and rapid detection of infection by loop-mediated isothermal amplification (LAMP) method. Experimental Parasitology 122(1): 47-50.

Zhang S, Zhou YH, Li L, Hu Y (2010) Monitoring human cytomegalovirus infection with nested PCR: comparison of positive rates in plasma and leukocytes and with quantitative PCR. Virology Journal, 7: 73 .

Zhou Y, Bian G, Zhou Q, Gao Z, Liao P, Liu Y, He M (2015) Detection of cytomegalovirus, human parvovirus B19, and herpes simplex virus-1/2 in women with first-trimester spontaneous abortions. Journal of Medical Virology 87(10): 1749-1753.

Zhou Y, Ushijima H, Frey TK (2007) Genomic analysis of diverse rubella virus genotypes. Journal of General Virology 88(Pt 3): 932-941.

Zhu Z, Xu W, Abernathy ES, Chen M-H, Zheng Q, Wang T, Zhang Z, Li C, Wang C, He W (2007) Comparison of four methods for confirming rubella virus infection using throat swabs. Journal of Clinical Microbiology 45(9): 2847-2852. 